\title{
Genetic characterization of clinical isolates of Clostridium difficile using an optimized RAPD protocol and PCR ribotyping reveals strain diversity between two tertiary referral Trusts in the West Midlands, UK
}

\author{
Lauren M. Green, Tony Worthington, Anthony C. Hilton and \\ Peter A. Lambert
}

Correspondence

Lauren M. Green

greenl1@aston.ac.uk

\author{
Aston University, School of Life \& Health Sciences, Aston Triangle, Birmingham B4 7ET, UK
}

Epidemiological investigations of Clostridium difficile often focus on differences between separate geographical areas. In this investigation, two populations of $C$. difficile recovered from separate tertiary referral Trusts within the West Midlands, UK, were characterized using both PCR ribotyping and an optimized RAPD (random amplification of polymorphic DNA) protocol. The PCR ribotyping and RAPD methodologies identified differences between the two C. difficile populations, in both the prevalence and the diversity of types identified. The use of PCR ribotyping in conjunction with RAPD further categorized different types within defined PCR ribotypes, identifying different types within the same PCR ribotype and therefore providing a greater discriminatory power than either of the methods when used alone. The differences observed in this study between the two Trusts in the distribution of both RAPD 'type' and PCR ribotype demonstrate the diversity that is present amongst isolates of $C$. difficile within a relatively small geographical area and warrants a need for further investigation into the local epidemiology of C. difficile.

Received 15 February 2011 Accepted 18 April 2011 and prevalence of PCR ribotypes of $C$. difficile within smaller geographical areas and therefore the localized distribution of PCR ribotypes is relatively unknown.

Currently within England and Northern Ireland, only three PCR ribotypes are responsible for over $50 \%$ of CDI cases (Health Protection Agency, 2009); this has led to PCR ribotyping no longer being discriminative enough to monitor the epidemiology of CDI (Tanner et al., 2010). Methods such as multi-locus variable number tandem repeat analysis (MLVA) are now becoming increasingly employed to type strains of $C$. difficile as they have the capacity to identify greater genotypic variability between isolates of $C$. difficile and identify 'subtypes' within PCR ribotypes (Killgore et al., 2008; Marsh et al., 2006; van den Berg et al., 2007). Subtyping within PCR ribotypes has also previously been demonstrated using other methods such as PFGE, REA and REP-PCR (Rahmati et al., 2005; Northey et al., 2005; Killgore et al., 2008; Fawley et al., 2008; Tanner et al., 2010). Despite this, accessibility, in addition to time and cost restraints, means that MLVA is still not widely utilized. Random amplification of polymorphic DNA (RAPD) PCR is a quick, cost-effective method which has previously been used to characterize $C$. difficile isolates (Barbut et al., 1994; Chachaty et al., 1994; van Dijck et al., 
1996). The method is often criticized, however, due to lack of reproducibility (Brazier, 1998). Optimization of the protocol has been shown to vastly improve reproducibility and therefore an optimized protocol was designed to determine if RAPD could be used to effectively discriminate between strains of $C$. difficile.

The aim of this study was to investigate the prevalence and distribution of different $C$. difficile PCR ribotypes between two tertiary referral Trusts within the West Midlands, UK, and also determine if RAPD could be utilized in the characterization and discrimination of isolates.

\section{METHODS}

Isolates. Sixty-two clinical toxigenic isolates of $C$. difficile were recovered from two tertiary referral Trusts within the West Midlands. Isolates were recovered from the Trusts between 2004 and 2005, with 30 of the isolates recovered from Trust A and 32 from Trust B. Eleven PCR ribotype reference isolates (001, 002, 005, 014, 015, 017, 023, 027, 064, 078 and 106) were kindly provided by HPA, Newcastle Laboratory, UK, and were used as comparisons for PCR ribotype profiles.

Isolation of C. difficile from faecal samples. Isolates were recovered from faecal samples using alcohol shock methodology, and following isolation were stored at $-70{ }^{\circ} \mathrm{C}$ using a Microbank Bacterial Preservation System until required.

PCR ribotyping. The PCR ribotyping technique used in this investigation was as described by Stubbs et al. (1999).

RAPD. The RAPD protocol used in this investigation had been optimized in previous studies to ensure the reproducibility and discriminatory power of the method (data not shown). Two $10 \mathrm{bp}$ primers, previously published by other authors, were used in reactions that were separate from and independent of each other. The primers used were AP3 (5'-TCA CGA TGC A-3') (Martirosian et al., 1995) and AP4 (5'-TCA CGC TGC A 3') (Barbut et al., 1993). Isolates were cultured onto Wilkins-Chalgren anaerobe agar and incubated for $24 \mathrm{~h}$ at $37{ }^{\circ} \mathrm{C}$ in an anaerobic cabinet. Colonies were then suspended in a $0.5 \%(\mathrm{w} / \mathrm{v})$ Chelex 100 resin suspension, which was briefly vortexed before being incubated in a water bath at $94{ }^{\circ} \mathrm{C}$ for $12 \mathrm{~min}$; a negative control containing only a suspension of Chelex 100 resin was also used for each experiment. Samples were then centrifuged for $10 \mathrm{~min}$ at $15000 \mathrm{~g}$ and the supernatant containing the crude DNA extract was used in the RAPD reaction; samples were stored at $4{ }^{\circ} \mathrm{C}$ until required. A total reaction volume of $25 \mu \mathrm{l}$ was used; concentrations for each of the components in the reactions were

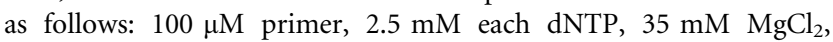
$25 \mathrm{mM} \mathrm{KCl}, 10 \mathrm{mM}$ Tris/HCl ( $\mathrm{pH} \mathrm{8.8),} 1.25 \mathrm{U}$ Taq polymerase and $2 \mu \mathrm{l}$ DNA sample. Amplification was carried out using cycles as follows: an initial cycle of $94{ }^{\circ} \mathrm{C}$ for $4.5 \mathrm{~min}, 5$ cycles of $94{ }^{\circ} \mathrm{C}$ for $30 \mathrm{~s}, 24{ }^{\circ} \mathrm{C}$ for $2 \mathrm{~min}$ and $72{ }^{\circ} \mathrm{C}$ for $1 \mathrm{~min}$ followed by 35 cycles of $94{ }^{\circ} \mathrm{C}$ for $30 \mathrm{~s}, 30{ }^{\circ} \mathrm{C}$ for $30 \mathrm{~s}$ and $72{ }^{\circ} \mathrm{C}$ for $1 \mathrm{~min}$, and a final extension of $5 \mathrm{~min}$ at $72{ }^{\circ} \mathrm{C}$. Following amplification, $5 \mu$ l loading buffer was added to the PCR samples and gel electrophoresis was carried out using a $2 \%(\mathrm{w} / \mathrm{v})$ agarose gel and performed in $1 \times \mathrm{TAE}$; $5 \mu \mathrm{DNA}$ ladder was added to the centre and end wells and $15 \mu \mathrm{lPCR}$ product was loaded into the remaining wells. Gels were run at $80 \mathrm{~V}$ for $1 \mathrm{~h}$ and $24 \mathrm{~min}$ until samples reached the end of the gel. To enable gels to be visualized, they were stained by soaking in $0.005 \%(\mathrm{w} / \mathrm{v})$ ethidium bromide solution for $20 \mathrm{~min}$ and then rinsed in sterile distilled water. Gels were visualized under UV light using the
GBOX-EF Gel Documentation System and images captured using Genesnap software.

Profile analysis. Amplicon profiles produced by both RAPD and PCR ribotyping were analysed using GelCompar II software.

Typeability and discriminatory power of PCR ribotyping and RAPD. The typeability and discriminatory power of PCR ribotyping and both primers used in the optimized RAPD protocol were calculated using Simpson's index of diversity $(D)$ using the equation $D=[1-\Sigma n(n-1)] / N(N-1)$, where $n$ is the total number of profiles characterized by an individual method, and $N$ is the total number of profiles for both methods.

\section{RESULTS}

\section{PCR ribotyping}

From the 62 isolates of $C$. difficile characterized, 12 distinct PCR ribotype profiles were identified. Six of these profiles could be matched to reference PCR ribotype profiles and therefore identified a distinct PCR ribotype. The frequency with which each of the PCR ribotypes occurred is presented in Table 1. The remaining six profiles, which represented $23 \%$ of the total isolates, could not be matched to any of the 11 reference profiles available and therefore the PCR ribotype of these isolates was designated 'undefined'. The PCR ribotypes most frequently identified amongst the group of isolates used in this investigation were 027 and 106 , with rates of $27 \%$ and $23 \%$ respectively; other PCR ribotypes identified were (rates indicated in parentheses) $001(8 \%), 002(6 \%), 014(8 \%)$ and $064(5 \%)$.

The distribution and number of PCR ribotypes amongst the isolates varied between the two tertiary referral trusts. Amongst the 32 isolates recovered from Trust A, 10 distinct PCR ribotype profiles were identified, but only six PCR ribotype profiles were identified amongst the 30 isolates recovered from Trust B. Isolates belonging to PCR ribotypes 027, 064, 106 and one undefined type were

Table 1. Frequency with which $P C R$ ribotypes occurred throughout the isolate population (percentage frequency indicated in parentheses)

\begin{tabular}{|lccc|}
\hline PCR ribotype & Trust A & Trust B & Total \\
\hline 001 & $5(16 \%)$ & 0 & $5(8 \%)$ \\
002 & $4(13 \%)$ & 0 & $4(6 \%)$ \\
014 & $5(16 \%)$ & 0 & $5(8 \%)$ \\
027 & $3(9 \%)$ & $14(47 \%)$ & $17(27 \%)$ \\
064 & $2(6 \%)$ & $1(3 \%)$ & $3(5 \%)$ \\
106 & $2(6 \%)$ & $12(40 \%)$ & $14(23 \%)$ \\
Undefined (a) & 0 & $1(3 \%)$ & $1(2 \%)$ \\
Undefined (b) & $1(3 \%)$ & 0 & $1(2 \%)$ \\
Undefined (c) & 0 & $1(3 \%)$ & $1(2 \%)$ \\
Undefined (d) & $2(6 \%)$ & 0 & $2(3 \%)$ \\
Undefined (e) & $4(13 \%)$ & $1(3 \%)$ & $5(8 \%)$ \\
Undefined (f) & $4(13 \%)$ & 0 & $4(6 \%)$ \\
& & & \\
\hline
\end{tabular}


found to be present in both Trusts, with the remaining types and profiles identified being exclusive to only one. Almost $80 \%$ of the isolates recovered from Trust A were identified as belonging to only five of the PCR ribotypes identified. Thirty-two per cent of isolates were found to belong to PCR ribotypes 001 and 014 , with each being found at equal frequency; PCR ribotype 002 and two undefined types were also each found in $13 \%$ of isolates recovered from this trust. Amongst the isolates recovered from Trust B, $87 \%$ belonged to PCR ribotypes 027 and 106; the four remaining PCR ribotypes that were identified were each represented by a single isolate.

\section{RAPD}

When the 62 isolates of $C$. difficile were characterized using primer AP3, 19 different RAPD types were identified. Thirteen different RAPD types were identified amongst isolates recovered from Trust A (Fig. 1), with six different types identified among isolates from Trust B (not shown). The frequency with which RAPD types (using primer AP3) were observed, and the Trusts from which they were recovered, are presented in Table 2(a). The RAPD profiles produced were exclusive to the location from which they were recovered, with no one type observed in isolates from both of the Trusts. As for PCR ribotyping, $87 \%$ of the isolates recovered from Trust B belonged to two RAPD types consisting of 11 and 15 isolates; each of the remaining four types identified were represented by a single isolate.

When both populations of $C$. difficile isolates were characterized using primer AP4, 10 different RAPD types were defined and in contrast to the results obtained when isolates were characterized using primer AP3, some isolates from both locations shared the same profile. Six different RAPD types were identified amongst isolates recovered from Trust A (Fig. 2), with two of these types also identified in isolates recovered from Trust B. The frequency

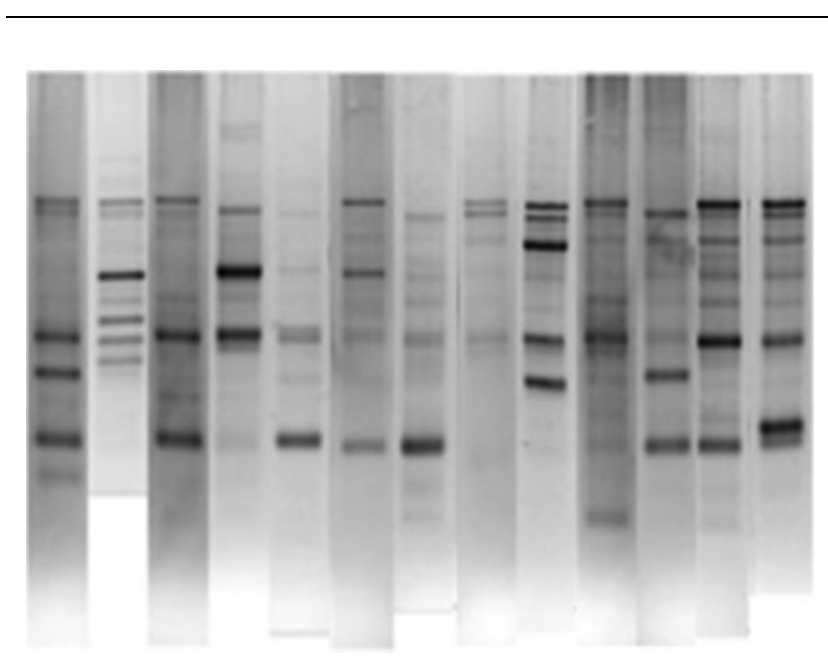

Fig. 1. RAPD profiles of isolates recovered from Trust $A$ and characterized using primer AP3.

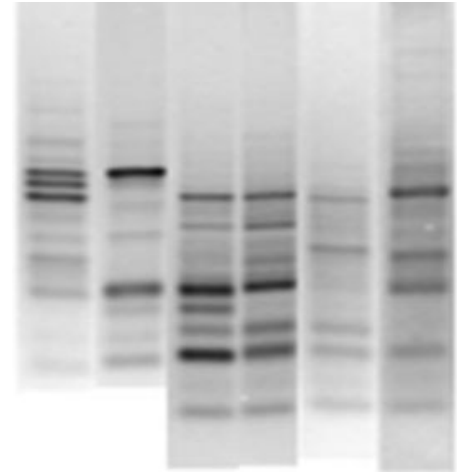

Fig. 2. RAPD profiles of isolates recovered from Trust $A$ and characterized using primer AP4.

with which RAPD types (using primer AP4) were observed, and the Trusts from which they were recovered, are presented in Table 2(b). Ninety per cent of the 62 isolates

Table 2. Frequency with which RAPD types, characterized using primer AP3 (a) and primer AP4 (b), occurred throughout the isolate population

\begin{tabular}{|lcc|}
\hline RAPD type & Trust A & Trust B \\
\hline (a) AP3 RAPD type & & \\
A & 3 & 0 \\
B & 7 & 0 \\
C & 1 & 0 \\
D & 3 & 0 \\
E & 0 & 1 \\
F & 2 & 0 \\
G & 3 & 0 \\
H & 5 & 0 \\
I & 2 & 0 \\
J & 2 & 0 \\
K & 1 & 0 \\
L & 1 & 0 \\
M & 1 & 0 \\
N & 1 & 0 \\
O & 0 & 11 \\
P & 1 \\
Q & 0 & 15 \\
R & 0 & 1 \\
S & 0 & 1 \\
(b) AP4 RAPD type & 0 & 1 \\
a & 0 & 0 \\
b & & 0 \\
c & 1 & 1 \\
d & 1 & 0 \\
e & 0 & 1 \\
f & 0 & \\
g & 1 & 0 \\
h & 0 & 1 \\
j & 0 & \\
\hline
\end{tabular}


were identified as belonging to four RAPD types, with the remaining six types each being represented by a single isolate.

\section{Characterization of isolates using both PCR ribotyping and RAPD}

Following characterization using both PCR ribotyping and RAPD, the data produced were then used in combination to further discriminate within PCR ribotypes (Table 3).When used to discriminate within PCR ribotypes, primer AP4 generally categorized to an equal or lesser number than primer AP3, with the exception of PCR ribotype 001. Isolates identified as belonging to the most common PCR ribotypes within the UK (001, 027 and 106)

Table 3. Distribution of defined RAPD types within PCR ribotypes

\begin{tabular}{|c|c|c|c|c|}
\hline $\begin{array}{l}\text { PCR } \\
\text { ribotype }\end{array}$ & $\begin{array}{c}\text { AP3 RAPD } \\
\text { type }\end{array}$ & $\begin{array}{l}\text { No. of } \\
\text { isolates }\end{array}$ & $\begin{array}{c}\text { AP4 RAPD } \\
\text { type }\end{array}$ & $\begin{array}{l}\text { No. of } \\
\text { isolates }\end{array}$ \\
\hline \multirow[t]{4}{*}{001} & B & 1 & a & 1 \\
\hline & D & 1 & $\mathrm{~d}$ & 1 \\
\hline & I & 2 & e & 2 \\
\hline & $\mathrm{J}$ & 1 & $\mathrm{j}$ & 1 \\
\hline \multirow[t]{4}{*}{002} & $\mathrm{C}$ & 1 & $\mathrm{~d}$ & 3 \\
\hline & $\mathrm{F}$ & 1 & e & 1 \\
\hline & $\mathrm{H}$ & 1 & & \\
\hline & K & 1 & & \\
\hline \multirow[t]{4}{*}{014} & A & 2 & $\mathrm{~d}$ & 1 \\
\hline & B & 1 & $\mathrm{e}$ & 4 \\
\hline & $\mathrm{D}$ & 1 & & \\
\hline & $\mathrm{M}$ & 1 & & \\
\hline \multirow[t]{4}{*}{027} & B & 1 & c & 1 \\
\hline & $\mathrm{H}$ & 2 & e & 3 \\
\hline & $\mathrm{O}$ & 3 & $\mathrm{f}$ & 13 \\
\hline & $\mathrm{Q}$ & 11 & & \\
\hline \multirow[t]{3}{*}{064} & A & 1 & d & 1 \\
\hline & $\mathrm{E}$ & 1 & e & 1 \\
\hline & $\mathrm{H}$ & 1 & $\mathrm{i}$ & 1 \\
\hline \multirow[t]{5}{*}{106} & G & 1 & $\mathrm{f}$ & 13 \\
\hline & $\mathrm{H}$ & 1 & $\mathrm{~h}$ & 1 \\
\hline & $\mathrm{O}$ & 8 & & \\
\hline & $\mathrm{Q}$ & 3 & & \\
\hline & $\mathrm{R}$ & 1 & & \\
\hline $\mathrm{U}(\mathrm{a})$ & Q & 1 & $\mathrm{f}$ & 1 \\
\hline $\mathrm{U}(\mathrm{b})$ & $\mathrm{F}$ & 1 & b & 1 \\
\hline $\mathrm{U}(\mathrm{c})$ & $S$ & 1 & g & 1 \\
\hline \multirow[t]{2}{*}{$\mathrm{U}(\mathrm{d})$} & B & 1 & $\mathrm{~d}$ & 1 \\
\hline & $\mathrm{J}$ & 1 & $\mathrm{f}$ & 1 \\
\hline \multirow[t]{4}{*}{$\mathrm{U}(\mathrm{e})$} & B & 2 & c & 1 \\
\hline & $\mathrm{L}$ & 1 & d & 2 \\
\hline & $\mathrm{N}$ & 1 & $\mathrm{f}$ & 2 \\
\hline & $\mathrm{P}$ & 1 & & \\
\hline \multirow[t]{3}{*}{$\mathrm{U}(\mathrm{f})$} & B & 1 & c & 3 \\
\hline & $\mathrm{D}$ & 1 & d & 1 \\
\hline & G & 2 & & \\
\hline
\end{tabular}

were further categorized into three RAPD types amongst those belonging to PCR ribotype 001, and into four RAPD types amongst those belonging to PCR ribotypes 027 and 106.

\section{Typeability and discriminatory power of PCR ribotyping and RAPD}

All isolates were typable by both PCR ribotyping and RAPD. Characterization of isolates using RAPD and primer AP3 demonstrated the greatest discriminatory power (0.89) followed by PCR ribotyping (0.86) and then RAPD using primer AP4 (0.58).

\section{DISCUSSION}

Both PCR ribotyping and RAPD produced similar patterns of profile distribution between the two locations, with both methods identifying greater variability throughout the population of isolates recovered from Trust A. Although there were similarities in the discriminatory power of the two methods, the defined types did not map directly on to each other; therefore RAPD type could not be used to predict PCR ribotype. There was also an overlap in the types observed; a single RAPD type was not exclusive to one PCR ribotype, possibly due to the targeting of different genomic targets by each of the methods. This similar pattern of distribution has also previously been observed in earlier phenotypic work which investigated the antibiogram profiles of 12 antibiotics in the same population of isolates (Green et al., 2010). The similar patterns of distribution observed between the two Trusts using PCR ribotyping, RAPD and antibiogram profiling is suggestive of an association between these methods; however, no association could be established.

This investigation highlighted differences in PCR ribotype epidemiology between the two Trusts despite their being relatively close geographically. Almost $90 \%$ of the isolates from Trust B belonged to PCR ribotypes 027 and 106; in contrast, the two predominant PCR ribotypes (001 and 014) recovered from Trust A represented only $32 \%$ of isolates. The reasons for such epidemiology are unknown and there are likely to be several contributing factors such as differences in infection control procedures and the demographics of the patients admitted. The predominance of only two PCR ribotypes (027 and 106) amongst isolates from Trust B may be indicative of hospital-acquired transmission, whereby the same strains of C. difficile continually circulate throughout a hospital environment. This observation is speculative, however, if based on PCR ribotyping information alone, due to limitations in the discriminatory power of PCR ribotyping. When RAPD profiling data were also applied to these predominant PCR ribotypes from Trust B, $11(37 \%)$ and $8(27 \%)$ of isolates identified as belonging to PCR ribotypes 027 and 106 respectively were also the same RAPD type. Although such characterization is not as discriminative as MLVA, the 
identification of these polymorphisms in isolates of C. difficile demonstrates how useful such methodologies can be in epidemiological studies, and especially outbreak situations. The PCR ribotype of over a third of isolates (34\%) recovered from Trust A and $10 \%$ of isolates from Trust B could not be identified due to the profiles not matching reference profiles of the 10 most common PCR ribotypes in England and Wales.

To conclude, the differences between the two Trusts in the distribution and prevalence of both RAPD 'type' and PCR ribotype demonstrate the diversity that is present in isolates of C. difficile within a relatively small geographical area. The use of PCR ribotyping in conjunction with RAPD has enabled greater discrimination of isolates than could be achieved using either of the methods alone; this is important for studying the epidemiology of CDI as it allows discrimination within PCR ribotypes.

\section{ACKNOWLEDGEMENTS}

We would like to thank Dr Andrew Sails of the HPA, Newcastle Laboratory, UK, for providing the PCR ribotype reference isolates.

\section{REFERENCES}

Barbut, F., Mario, N., Frottier, J. \& Petit, J. C. (1993). Use of the arbitrary primer polymerase chain reaction for investigating an outbreak of Clostridium difficile-associated diarrhea in AIDS patients. Eur J Clin Microbiol Infect Dis 12, 794-795.

Barbut, F., Mario, N., Meyohas, M. C., Binet, D., Frottier, J. \& Petit, J. C. (1994). Investigation of a nosocomial outbreak of Clostridium difficile-associated diarrhoea among AIDS patients by random amplified polymorphic DNA (RAPD) assay. J Hosp Infect 26, 181-189.

Brazier, J. S. (1998). The epidemiology and typing of Clostridium difficile. J Antimicrob Chemother 41 (Suppl. C), 47-57.

Chachaty, E., Saulnier, P., Martin, A., Mario, N. \& Andremont, A. (1994). Comparison of ribotyping, pulsed-field gel electrophoresis and random amplified polymorphic DNA for typing Clostridium difficile strains. FEMS Microbiol Lett 122, 61-68.

Fawley, W. N., Freeman, J., Smith, C., Harmanus, C., van den Berg, R. J., Kuijper, E. J. \& Wilcox, M. H. (2008). Use of highly discriminatory fingerprinting to analyze clusters of Clostridium difficile infection cases due to epidemic ribotype 027 strains. J Clin Microbiol 46, 954960.

Green, L. M., Worthington, T., Hilton, A. C. \& Lambert, P. A. (2010). Phenotypic characterisation of Clostridium difficile reveals lack of extracellular virulence factor production and significant differences in antibiogram profiles. Int J Antimicrob Agents 35, 305-306.

Health Protection Agency (2009). Clostridium difficile ribotyping network for England and Northern Ireland 2008/09 report. November 2009. http://www.hpa.org.uk/web/HPAwebFile/HPAweb_C/1258560554236.

Health Protection Agency (2010). Quarterly Epidemiological Commentary Mandatory MRSA bacteraemia and Clostridium difficile infection (October 2007 to December 2009). March 2010. http:// www.hpa.org.uk/web/HPAwebFile/HPAweb_C/1267551242367

Killgore, G., Thompson, A., Johnson, S., Brazier, J. S., Kuijper, E., Pepin, J., Frost, E. H., Savelkoul, P., Nicholson, B. \& other authors (2008). Comparison of seven techniques for typing international epidemic strains of Clostridium difficile: restriction endonuclease analysis, pulsed-field gel electrophoresis, PCR-ribotyping, multilocus sequence typing, multilocus variable-number tandem-repeat analysis, amplified fragment length polymorphism, and surface layer protein A gene sequence typing. J Clin Microbiol 46, 431-437.

Kuijper, E. J., Barbut, F., Brazier, J. S., Kleinkauf, N., Eckmanns, T., Lambert, M. L., Drudy, D. L., Fitzpatrick, F., Wiuff, C. \& other authors (2008). Update of Clostridium difficile infection due to PCR ribotype 027 in Europe, 2008. Euro Surveill 13, 433-439.

Loo, V. G., Poirier, L., Miller, M. A., Oughton, M., Libman, M. D., Michaud, S., Bourgault, A. M., Nguyen, T., Frenette, C. \& other authors (2005). A predominantly clonal multi-institutional outbreak of Clostridium difficile-associated diarrhea with high morbidity and mortality. N Engl J Med 353, 2442-2449.

Marsh, J. W., O'Leary, M. M., Shutt, K. A., Pasculle, A. W., Johnson, S., Gerding, D. N., Muto, C. A. \& Harrison, L. H. (2006). Multilocus variable-number tandem-repeat analysis for investigation of Clostridium difficile transmission in hospitals. J Clin Microbiol 44, 2558-2566.

Martirosian, G., Kuipers, S., Verbrugh, H., van Belkum, A. \& MeiselMikolajczyk, F. (1995). PCR ribotyping and arbitrarily primed PCR for typing strains of Clostridium difficile from a Polish maternity hospital. J Clin Microbiol 33, 2016-2021.

McDonald, L. C., Killgore, G. E., Thompson, A., Owens, R. C., Jr, Kazakova, S. V., Sambol, S. P., Johnson, S. \& Gerding, D. N. (2005). An epidemic, toxin gene-variant strain of Clostridium difficile. $N$ Engl J Med 353, 2433-2441.

Northey, G., Gal, M., Rahmati, A. \& Brazier, J. S. (2005). Subtyping of Clostridium difficile PCR ribotype 001 by REP-PCR and PFGE. J Med Microbiol 54, 543-547.

Rahmati, A., Gal, M., Northey, G. \& Brazier, J. S. (2005). Subtyping of Clostridium difficile polymerase chain reaction (PCR) ribotype 001 by repetitive extragenic palindromic PCR genomic fingerprinting. J Hosp Infect 60, 56-60.

Stubbs, S. L., Brazier, J. S., O'Neill, G. L. \& Duerden, B. I. (1999). PCR targeted to the 16S-23S rRNA gene intergenic spacer region of Clostridium difficile and construction of a library consisting of 116 different PCR ribotypes. J Clin Microbiol 37, 461-463.

Tanner, H. E., Hardy, K. J. \& Hawkey, P. M. (2010). Coexistence of multiple multilocus variable-number tandem-repeat analysis subtypes of Clostridium difficile PCR ribotype 027 strains within fecal specimens. J Clin Microbiol 48, 985-987.

van den Berg, R. J., Schaap, I., Templeton, K. E., Klaassen, C. H. W. \& Kuijper, E. J. (2007). Typing and subtyping of Clostridium difficile isolates by using multiple-locus variable-number tandem-repeat analysis. J Clin Microbiol 45, 1024-1028.

van Dijck, P., Avesani, V. \& Delmée, M. (1996). Genotyping of outbreak-related and sporadic isolates of Clostridium difficile belonging to serogroup C. J Clin Microbiol 34, 3049-3055.

Warny, M., Pepin, J., Fang, A., Killgore, G., Thompson, A., Brazier, J., Frost, E. \& McDonald, L. C. (2005). Toxin production by an emerging strain of Clostridium difficile associated with outbreaks of severe disease in North America and Europe. Lancet 366, 1079-1084. 